\title{
Factors associated with the progression of fibrosis on liver biopsy in Alaska Native and American Indian persons with chronic hepatitis $\mathrm{C}$
}

\author{
Stephen E Livingston MD¹, Heike Deubner MD², Dana L Bruden $\mathrm{MS}^{3}$, Brian J McMahon MD ${ }^{1,3}$, Chriss E Homan BS¹,
} Lisa J Townshend-Bulson ANP1 ${ }^{1}$, Michael G Bruce MD MPH ${ }^{3}$, Thomas W Hennessy MD MPH ${ }^{3}$,

James L Williams ANP1, David R Gretch MD PhD²

SE Livingston, H Deubner, DL Bruden, et al. Factors associated with the progression of fibrosis on liver biopsy in Alaska Native and American Indian persons with chronic hepatitis C. Can J Gastroenterol 2010;24(7):445-451.

BACKGROUND: Various factors influence the development and rate of fibrosis progression in chronic hepatitis $\mathrm{C}$ virus (HCV) infection. OBJECTIVES: To examine factors associated with fibrosis in a longterm outcomes study of Alaska Native/American Indian persons who underwent liver biopsy, and to examine the rate of fibrosis progression in persons with subsequent biopsies.

METHODS: A cross-sectional analysis of the demographic, inflammatory and viral characteristics of persons undergoing liver biopsy compared individuals with early (Ishak fibrosis score of lower than 3) with those with advanced (Ishak score of 3 or greater) fibrosis. Persons who underwent two or more biopsies were analyzed for factors associated with fibrosis progression.

RESULTS: Of $253 \mathrm{HCV}$ RNA-positive persons who underwent at least one liver biopsy, 76 (30\%) had advanced fibrosis. On multivariate analysis, a Knodell histological activity index score of 10 to 14 and an alpha-fetoprotein level of $8 \mathrm{ng} / \mathrm{mL}$ or higher were found to be independent predictors of advanced liver fibrosis ( $\mathrm{P}<0.0001$ for each). When surrogate markers of liver inflammation (alanine aminotransferase, aspartate aminotransferase/alanine aminotransferase ratio and alpha-fetoprotein) were removed from the model, type 2 diabetes mellitus $(\mathrm{P}=0.001)$, steatosis $(\mathrm{P}=0.03)$ and duration of HCV infection by 10 -year intervals $(\mathrm{P}=0.02)$ were associated with advanced fibrosis. Among 52 persons who underwent two or more biopsies a mean of 6.2 years apart, the mean Ishak fibrosis score increased between biopsies $(\mathrm{P}=0.002)$, with progression associated with older age at initial biopsy and HCV risk factors.

CONCLUSIONS: The presence of type 2 diabetes mellitus, steatosis and duration of $\mathrm{HCV}$ infection were independent predictors of advanced fibrosis in the present cohort, with significant fibrosis progression demonstrated in persons who underwent serial biopsies.
Facteurs associés à la progression de la fibrose à la biopsie hépatique chez des Amérindiens d'Alaska souffrant d'hépatite $\mathrm{C}$ chronique

CONTEXTE : Plusieurs facteurs influent sur l'apparition de la fibrose et la vitesse de sa progression dans l'hépatite $\mathrm{C}$ chronique (causée par le VHC).

OBJECTIFS : Examiner les facteurs associés à la fibrose dans une étude pronostique à long terme chez des Amérindiens d'Alaska ayant subi une biopsie hépatique. Examiner la vitesse de progression de la fibrose chez des personnes ayant subi des biopsies successives.

MÉTHODES : Une analyse transversale des caractéristiques démographiques, inflammatoires et virales des patients soumis à une biopsie du foie a comparé ceux qui présentaient un début de fibrose (score Ishak de fibrose inférieur à 3 ) à ceux dont la fibrose était avancée (score Ishak de 3 ou plus). Les auteurs ont étudiés les cas soumis à deux biopsies ou plus pour ce qui est des facteurs associés à la progression de la fibrose. RÉSULTATS : Sur 253 personnes positives à l'égard de l'ARN du VHC ayant subi au moins une biopsie hépatique, 76 (30\%) présentaient une fibrose. À l'analyse multivariée, un index d'activité histocytologique de Knodell de 10 à 14 et un taux d'alpha-fœtoprotéine de $8 \mathrm{ng} / \mathrm{mL}$ ou plus se sont révélés être des prédicteurs indépendants de fibrose hépatique avancée $(\mathrm{P}<0,0001$ pour chacun). Lorsque des marqueurs substituts de l'inflammation hépatique (alanine aminotransférase, rapport aspartate aminotransférase:alanine aminotransférase et alpha-fétoprotéine) ont été éliminés du modèle, le diabète de type $2(\mathrm{P}=0,001)$, la stéatose $(\mathrm{P}=0,03)$ et la durée de l'infection au VHC par tranches de dix ans $(P=0,02)$ ont été associés à une fibrose avancée. Chez les 52 personnes qui ont subi deux biopsies ou plus à 6,2 ans d'intervalle en moyenne, le score Ishak de fibrose moyen augmentait d'une biopsie à l'autre $(\mathrm{P}=0,002)$, la progression étant associée à un âge plus avancé au moment de la biopsie initiale et aux facteurs de risque à l'égard du VHC.

CONCLUSIONS : La présence de diabète de type 2, de stéatose et la durée de l'infection au VHC ont été des prédicteurs indépendants de la fibrose avancée dans la présente cohorte, avec une progression significative de la fibrose chez les patients ayant subi plusieurs biopsies.

Key Words: Hepatitis C; Liver fibrosis; Liver steatosis

Chronic hepatitis $\mathrm{C}$ virus (HCV) infection is generally a Slow, progressive disease, with various factors believed to influence the development and rate of liver fibrosis. Although invasive, and having limitations such as sampling variation and observer error, liver biopsy is considered to be the gold standard for evaluation of fibrosis stage. Time-related patient demographics, such as duration of HCV infection, age at infection and age at biopsy, have been associated with fibrosis stage or progression of fibrosis (1-3). Surrogate liver inflammatory markers, such as aspartate aminotransferase (AST)/alanine aminotransferase (ALT) ratio, ALT level and alpha-fetoprotein (AFP) level, have also been associated with the presence of fibrosis (4-7). Some investigators have evaluated disease progression by comparing serial biopsies, usually in treatment-naive patients (6-8).

Most studies of liver fibrosis have been performed on clinic patients, many of whom were referred for treatment evaluation;

${ }^{1}$ Liver Disease and Hepatitis Program, Alaska Native Tribal Health Consortium Liver Disease Ë Hepatitis Program, Anchorage, Alaska;

${ }^{2}$ University of Washington School of Medicine, Seattle, Washington; ${ }^{3}$ Arctic Investigations Program, Division of Emerging Infections and

Surveillance Services, National Center for Preparedness, Detection and Control of Infectious Diseases, Centers for Disease Control and

Prevention, Anchorage, Alaska, USA

Correspondence: Dr Stephen E Livingston, Alaska Native Tribal Health Consortium Liver Disease Eु Hepatitis Program,

4315 Diplomacy Drive, Anchorage, Alaska 99508, USA. Telephone 907-729-1565, fax 907-729-1570, e-mail slivings@anthc.org

Received for publication September 24, 2009. Accepted December 14, 2009 
these studies have not necessarily been population based. There have been no published studies examining the factors associated with liver fibrosis in indigenous populations with chronic HCV infection. Since 1994, more than 1000 Alaska Native and American Indian persons living in Alaska have been enrolled in a long-term HCV outcomes study (9). The prevalence of $\mathrm{HCV}$ infection and risk factor profile in this population is similar to that of the general population of the United States (9). The present study compared the characteristics of biopsied individuals who had advanced versus early fibrosis in this cohort. We also investigated the factors associated with disease progression in those who underwent serial biopsies.

\section{METHODS}

\section{Patients}

Patients in the present study were selected from a long-term HCV outcomes study of Alaska Native and American Indian persons that began in January 1994. Nine hundred sixty antiHCV-positive individuals from all areas of Alaska consented to participate in the study through December 2005, of whom 715 were HCV RNA positive. Of the cohort, 279 treatment-naive persons underwent liver biopsy, 264 of whom were HCV RNA positive at the time of consent. Liver biopsy was performed only for clinical reasons and according to practice guidelines for HCV infection published by the American Association for the Study of Liver Diseases (10), primarily to evaluate possible treatments. Thirteen patients who underwent liver biopsy before 1994 were subsequently included because they consented to the study and had stored sera available for HCV RNA testing, which was obtained before consent. Fifty-three persons underwent two or more biopsies; the most recent biopsy result was used for a cross-sectional analysis comparing characteristics of those with advanced fibrosis versus those with early fibrosis. Nine individuals who underwent a second biopsy after 2005 were included in this part of the analysis. All individuals who underwent multiple biopsies were untreated for a variety of reasons including an initial biopsy that showed no or mild fibrosis, medical or psychological contraindications or a personal desire for no treatment. Subsequent liver biopsies were also performed only for clinical reasons to determine whether disease progression had occurred, as per clinical practice guidelines (10). In persons who had undergone multiple biopsies, 16 underwent more than two biopsies. For these individuals, the first and most recent biopsies were used to calculate fibrosis progression.

Medical records were also reviewed to determine how many persons developed decompensated liver disease, hepatocellular carcinoma or liver-related death after biopsy. Decompensated liver disease was defined as the presence of one or more of the following: ascites, esophageal varices, hepatic encephalopathy or coagulopathy. The diagnosis of ascites was made using paracentesis or by imaging with ultrasound, computerized axial tomography or magnetic resonance imaging. Esophageal varices were diagnosed using esophagogastroduodenoscopy or coincidental findings on imaging. Hepatic encephalopathy was diagnosed by clinical findings of mental impairment consistent with encephalopathy, a positive numbers connection test or the presence of asterixis. Coagulopathy was defined as a prothrombin time of more than $2 \mathrm{~s}$ above the upper limit of normal or elevated international normalized ratio.
Approval for the present study was obtained from the Institutional Review Boards of the Alaska Area Native Health Services in Anchorage (Alaska), the University of Washington Medical Center (Washington, USA) and the Centers for Disease Control and Prevention (Georgia, USA), as well as three regional Alaska Native health corporation boards. All patients provided informed written consent to participate in the present study.

\section{Laboratory testing}

ALT and AST testing was performed at the Alaska Native Medical Center laboratory (Anchorage, Alaska) on an Aeroset Chemistry analyzer (Abbott Laboratories, USA). An ALT level of lower than $40 \mathrm{U} / \mathrm{L}$ was defined as normal. AFP testing was performed at the same laboratory by microparticle enzyme immunoassay on an AxSYM analyzer (Abbott Laboratories, USA). An AFP level of lower than $8 \mathrm{ng} / \mathrm{mL}$ was defined as normal. Testing for HCV RNA and HCV genotype was performed at the University of Washington Medical Center. HCV RNA levels were determined using the branched DNA assay version 2.0 (Bayer Corporation, USA) and by quantitative reverse transcription polymerase chain reaction. The limit of detection of the branched DNA assay is 200,000 genome equivalents $/ \mathrm{mL}$. These results were converted to $\mathrm{IU} / \mathrm{mL}$ using the manufacturer's recommended conversion factor of 5.8 genome equivalents $/ \mathrm{mL}$ to $1 \mathrm{IU} / \mathrm{mL}$. For samples that tested negative by branched-chain DNA assay, an end point dilution assay was performed using the Roche Amplicor system (Roche Diagnostic Systems, USA), with a lower limit of 100 copies/mL. HCV genotyping was performed by restriction fragment length polymorphism analysis of the $5^{\prime}$-noncoding region, as described previously (11).

\section{Histological evaluation of liver biopsies}

Liver biopsy slides were evaluated by a study pathologist (HD) who was blinded to patient identity and demographic, clinical and biological data. Inflammation was evaluated using the Knodell histological activity index (HAI) (12). Fibrosis was evaluated using the Ishak system (13). Individuals with Ishak fibrosis scores of 0 to 2 , and 3 to 6 , were categorized as having early and advanced fibrosis, respectively.

\section{Statistical analysis}

Individuals who underwent liver biopsy were compared with those in the cohort not undergoing biopsy for age at infection and consent; sex; residence (urban versus rural); median levels of ALT and AST, AST/ALT ratio and median AFP level (all at time of consent); history of heavy alcohol use ever or at consent ( $50 \mathrm{~g} /$ day or greater); presence of hepatitis $\mathrm{B}$ virus core antibody; risk factors (intravenous drug use, blood transfusion or other); HCV duration of infection; and HCV RNA level and genotype. The estimated date of infection was determined using historical risk factor data and the results from tests of stored sera as previously described (14). A cross-sectional analysis was performed to examine risk factors for the presence of advanced fibrosis at the time of liver biopsy. Univariate comparisons between persons who underwent liver biopsy and those who did not, as well as between persons with advanced and early fibrosis were made using the likelihood ratio $\chi^{2}$ test and the Wilcoxon's rank sum test for categorical and 
continuous variables, respectively. Explanatory variables that were considered in this model were as follows: sex; age at consent date; urban residence; body mass index of $30 \mathrm{~kg} / \mathrm{m}^{2}$ or greater at consent; type 2 diabetes mellitus; Knodell HAI; presence of steatosis on biopsy; heavy alcohol consumption at consent or time of biopsy; ALT levels and AST/ALT ratio at biopsy; hepatitis B virus antibody status; estimated duration of $\mathrm{HCV}$ infection and age at HCV infection date; and HCV genotype and RNA level at biopsy. The mean Ishak score was compared between groups using the Mantel-Haenszel $\chi^{2}$ test.

Two multivariate models were developed through the use of a $\log$ binomial model. The first model aimed to identify factors that predicted advanced liver fibrosis, included surrogate markers of liver inflammation (eg, ALT, AST/ALT ratio and AFP), while the second model removed these markers and attempted to distinguish factors that contributed to disease progression. Purposeful forward selection was used to evaluate main effects. After the selection of main effects, twoway interactions of clinical interest were considered. All statistical analyses were performed using StatXact version 6 (Cytel Software Corp, USA) and SAS version 9.1 (SAS Institute Inc, USA).

HCV treatment-naive individuals who had undergone two or more liver biopsies were selected for analysis of fibrosis progression. Only persons with an Ishak score of 4 or lower on initial biopsy were considered in this analysis. One person who was biopsied twice had an Ishak fibrosis score of 6 on both occasions and was omitted from further analysis, leaving 52 persons in the group. Fibrosis progression was calculated by dividing the change in Ishak score by the number of years between liver biopsy dates. The association with sex, age at initial biopsy, body mass index, Knodell HAI, genotype, duration of HCV infection, risk factors, viral load and ALT level at initial biopsy date, was tested using generalized linear models with a normal response.

\section{RESULTS}

Baseline characteristics of persons with and without liver biopsy

Fifty-three per cent of patients were biopsied within one year of consenting to participate in the present study, and $74 \%$ within three years. Of the $264 \mathrm{HCV}$ RNA-positive persons who underwent liver biopsy, eight were coinfected with HIV and three with the hepatitis B virus. Because sample sizes precluded investigation of the effects of coinfection, these 11 persons were excluded from further analysis. Baseline characteristics of the remaining 253 persons who underwent liver biopsy were compared with 432 consenting HCV RNA-positive individuals who were not biopsied (Table 1). Persons who underwent biopsy had a significantly higher median ALT and AST levels at consent than those not biopsied $(\mathrm{P}<0.001)$; a higher median AFP level at consent $(\mathrm{P}<0.05)$; were younger at time of infection $(\mathrm{P}<0.05)$; and were more likely to have an HCV RNA level of $500,000 \mathrm{IU} / \mathrm{mL}$ or higher $(\mathrm{P}<0.05)$. A higher percentage of persons not biopsied had an AST/ALT ratio of one or greater $(P<0.05)$. There was no significant difference in the two groups regarding age at consent, sex, urban versus rural residence, heavy alcohol use, presence of hepatitis B core antibody, risk factors, duration of infection or proportion infected with HCV genotype 1 .
TABLE 1

Comparison of characteristics of hepatitis C virus (HCV) RNA-positive Alaska Native and American Indian persons in a long-term hepatitis C outcomes study with and without liver biopsy

\begin{tabular}{|c|c|c|}
\hline & $\begin{array}{l}\text { Biopsied } \\
(n=253)\end{array}$ & $\begin{array}{l}\text { Not biopsied } \\
\quad(n=432)\end{array}$ \\
\hline Age at consent, years & $41(35-46)$ & $42(37-47)$ \\
\hline Female, \% & 49 & 51 \\
\hline Urban dwelling, \% & 63 & 63 \\
\hline Median ALT, U/L & $83(59-149)$ & $56(38-97)^{\star \star}$ \\
\hline Median AST, U/L & $59(41-97)$ & $43(30-75)^{\star \star}$ \\
\hline AST/ALT ratio $(\geq 1), \%$ & 16 & $24^{\star}$ \\
\hline Median AFP, ng/mL & $3.4(2.5-5.4)$ & $3.1(2.3-4.8)^{\star}$ \\
\hline Alcohol at consent >50 g/day, $\%$ & 11 & 12 \\
\hline History of alcohol >50 g/day, \% & 34 & 32 \\
\hline Hepatitis B virus core antibody, \% & 26 & 24 \\
\hline \multicolumn{3}{|l|}{ Risk factor, \% } \\
\hline Intravenous drug use & 64 & 58 \\
\hline Blood transfusion & 13 & 15 \\
\hline Other & 23 & 25 \\
\hline Age at infection, years & $25(19-31)$ & $27(20-35)^{\star}$ \\
\hline HCV duration of infection & $14(6-21)$ & $12(4-21)$ \\
\hline HCV RNA positive, \% & 100 & 100 \\
\hline HCV genotype 1, \% & 64 & 64 \\
\hline HCV RNA $\geq 5 \times 10^{5} \mathrm{IU}, \%$ & 57 & $48^{*}$ \\
\hline
\end{tabular}

Data presented as median (interquartile range) unless indicated otherwise. AFP Alpha-fetoprotein; ALT Alanine aminotransferase; AST Aspartate aminotransferase. ${ }^{\star} P<0.05 ;{ }^{*} P<0.001$

Histological results of liver biopsies

The Ishak fibrosis scores of the 253 persons evaluated were as follows: $0(n=31,12 \%) ; 1(n=51,20 \%) ; 2(n=95,38 \%) ; 3(n=31$, $12 \%) ; 4(n=16,6 \%) ; 5(n=10,4 \%)$ and $6(n=19,8 \%)$. The overall prevalence of advanced fibrosis was 30\% (76 of 253). Knodell HAI scores among this group were as follows: 2 to $5(\mathrm{n}=40,16 \%) ; 6$ to $7(\mathrm{n}=81,32 \%) ; 8$ to $9(\mathrm{n}=74,29 \%)$ and 10 to $14(\mathrm{n}=58,23 \%)$.

Comparison of persons with early and advanced fibrosis On univariate analysis, advanced liver fibrosis was associated with age at biopsy of 40 years or older $(\mathrm{P}=0.04)$; presence of steatosis $(\mathrm{P}=0.01)$; increasing Knodell HAI score $(\mathrm{P}<0.0001)$; presence of type 2 diabetes mellitus $(\mathrm{P}<0.0001)$; elevated ALT level $(\mathrm{P}<0.0001)$; AST/ALT ratio of one or greater $(\mathrm{P}=0.002)$; AFP level of $8 \mathrm{ng} / \mathrm{mL}$ or higher $(\mathrm{P}<0.0001)$; and increased duration of HCV infection ( $\mathrm{P}=0.003)$ (Table 2$)$. The mean Ishak score was associated with the same factors plus sex $(\mathrm{P}=0.02)$.

Characteristics that had $\mathrm{P} \leq 0.25$ on univariate analysis were considered in the multivariate model. On multivariate analysis, a Knodell HAI score of 10 to 14, versus 2 to 5 (prevalence ratio 6.9, 95\% CI 2.2 to 22.2; $\mathrm{P}<0.0001$ ) and AFP level of $8 \mathrm{ng} / \mathrm{mL}$ or higher (prevalence ratio $1.8,95 \%$ CI 1.3 to 2.5 ; $\mathrm{P}<0.0001$ ) were independent predictors of advanced liver fibrosis. In a second multivariate model, surrogate markers of liver inflammation (ALT, AST/ALT ratio and AFP) were removed and type 2 diabetes mellitus (prevalence ratio $1.8,95 \%$ CI 1.2 to 2.7; $\mathrm{P}=0.001$ ), steatosis (prevalence ratio $1.5,95 \% \mathrm{CI} 1.0$ to 2.3; $\mathrm{P}=0.03$ ) and duration of HCV infection by 10 -year intervals (prevalence ratio $1.3,95 \% \mathrm{CI} 1.1$ to $1.6 ; \mathrm{P}=0.02$ ) were associated with advanced liver fibrosis. 
TABLE 2

Comparison of 253 hepatitis C virus (HCV) RNA-positive Alaska Native and American Indian persons with advanced versus early fibrosis on liver biopsy*

\begin{tabular}{|c|c|c|c|c|c|}
\hline Characteristic & $\begin{array}{l}\text { Advanced liver } \\
\text { fibrosis, \% (n/n) }\end{array}$ & $\begin{array}{c}\text { Prevalence } \\
\text { ratio }(95 \% \mathrm{Cl})\end{array}$ & $\mathbf{P}$ & $\begin{array}{c}\text { Ishak } \\
\text { score, mean }\end{array}$ & $\mathbf{P}$ \\
\hline Sex & & & 0.54 & & 0.02 \\
\hline Male & $32(41 / 129)$ & $1.1(0.8-1.6)$ & & 2.4 & \\
\hline Female & $28(35 / 124)$ & Reference & & 2.0 & \\
\hline Age at biopsy, years & & & 0.04 & & 0.0002 \\
\hline$<40$ & $22(20 / 91)$ & $1.6(1.0-2.4)$ & & 1.7 & \\
\hline$\geq 40$ & $35(56 / 162)$ & Reference & & 2.5 & \\
\hline Residence & & & 0.95 & & 0.80 \\
\hline Rural & $30(28 / 94)$ & $1.0(0.7-1.5)$ & & 2.3 & \\
\hline Urban & $30(48 / 159)$ & Reference & & 2.2 & \\
\hline Steatosis $^{\dagger}$ & & & 0.01 & & 0.001 \\
\hline Yes & $37(46 / 126)$ & $1.7(1.1-2.6)$ & & 2.5 & \\
\hline No & $21(23 / 107)$ & Reference & & 1.8 & \\
\hline Knodell histological activity index ${ }^{\dagger}$ & & & $<0.0001$ & & $<0.0001$ \\
\hline 2 to 5 & $8(3 / 39)$ & Reference & & 1.3 & \\
\hline 6 to 7 & $18(14 / 79)$ & $2.3(0.7-7.5)$ & & 1.8 & \\
\hline 8 to 9 & $25(18 / 73)$ & $3.2(1.0-10.2)$ & & 2.2 & \\
\hline 10 to 14 & $70(39 / 56)$ & $9.0(3.0-27.2)$ & & 3.5 & \\
\hline Body mass index $\geq 30^{\dagger}$ & & & 0.35 & & 0.67 \\
\hline Yes & $33(29 / 94)$ & $1.2(0.8-1.8)$ & & 2.2 & \\
\hline No & $27(36 / 136)$ & Reference & & 2.3 & \\
\hline Type 2 diabetes mellitus & & & $<0.0001$ & & $<0.0001$ \\
\hline Yes & $64(16 / 25)$ & $2.4(1.7-3.5)$ & & 3.8 & \\
\hline No & $26(57 / 228)$ & Reference & & 2.0 & \\
\hline Alcohol >50 g/day & & & 0.83 & & 0.29 \\
\hline Yes & $28(5 / 18)$ & $0.9(0.4-2.0)$ & & 2.6 & \\
\hline No & $30(71 / 235)$ & Reference & & 2.2 & \\
\hline Alanine aminotransferase (upper limit of normal [ULN] = $40 \mathrm{U} / \mathrm{L}$ ) & & & $<0.0001$ & & $<0.0001$ \\
\hline$<U L N$ & $11(3 / 26)$ & Reference & & 1.5 & \\
\hline $1-2 \times$ ULN & $20(16 / 81)$ & $1.7(0.5-5.4)$ & & 1.7 & \\
\hline $2-3 \times$ ULN & $32(20 / 62)$ & $2.8(0.9-8.6)$ & & 2.4 & \\
\hline$>3 \times$ ULN & $44(37 / 84)$ & $3.8(1.3-11.4)$ & & 2.8 & \\
\hline Aspartate aminotransferase/alanine aminotransferase ratio $\geq 1$ & & & 0.002 & & 0.0002 \\
\hline Yes & $50(21 / 42)$ & $1.9(1.4-5.6)$ & & 3.1 & \\
\hline No & $26(52 / 211)$ & Reference & & 2.1 & \\
\hline Alpha-fetoprotein $\geq 8 \mathrm{ng} / \mathrm{mL}^{\dagger}$ & & & $<0.0001$ & & $<0.0001$ \\
\hline Yes & $67(29 / 43)$ & $3.0(2.2-4.2)$ & & 3.7 & \\
\hline No & $22(46 / 206)$ & Reference & & 1.9 & \\
\hline HCV infection duration, years & & & 0.003 & & 0.0005 \\
\hline$\leq 10$ & $19(16 / 85)$ & $1.3(1.1-1.6)^{\ddagger}$ & & 1.8 & \\
\hline 11 to $\leq 20$ & $33(26 / 80)$ & & & 2.3 & \\
\hline$>20$ & $39(34 / 88)$ & & & 2.6 & \\
\hline Age at infection, years & & & 0.34 & & 0.32 \\
\hline$\leq 20$ & $35(29 / 82)$ & & & 2.3 & \\
\hline 21 to $\leq 30$ & $29(27 / 92)$ & $0.9(0.7-1.1)^{\ddagger}$ & & 2.2 & \\
\hline$\geq 31$ & $25(20 / 79)$ & & & 2.1 & \\
\hline Risk factor & & & 0.27 & & 0.25 \\
\hline Intravenous drug use & $31(50 / 162)$ & Reference & & 2.2 & \\
\hline Blood transfusion & $38(13 / 34)$ & $1.2(0.8-2.0)$ & & 2.6 & \\
\hline Other & $22(13 / 57)$ & $0.7(0.4-1.2)$ & & 2.0 & \\
\hline HCV genotype & & & 0.38 & & 0.20 \\
\hline 1 & $27(44 / 161)$ & Reference & & 2.1 & \\
\hline 2 & $32(17 / 53)$ & $1.2(0.7-1.9)$ & & 2.2 & \\
\hline 3 & $38(15 / 39)$ & $1.4(0.9-2.3)$ & & 2.6 & \\
\hline $\mathrm{HCV}_{\mathrm{RNA}}{ }^{\dagger}$ & & & 0.30 & & 0.50 \\
\hline$\geq 5 \times 10^{5} \mathrm{IU} / \mathrm{mL}$ & $33(43 / 130)$ & $1.2(0.8-1.8)$ & & 2.3 & \\
\hline$<5 \times 10^{5} \mathrm{IU} / \mathrm{mL}$ & $27(33 / 122)$ & Reference & & 2.2 & \\
\hline
\end{tabular}

${ }^{\star}$ Early fibrosis defined as an Ishak fibrosis score of 0 to 2; advanced fibrosis defined as an Ishak fibrosis score of 3 to 6 ; ${ }^{\dagger} n<253$ for this characteristic; ${ }^{\ddagger}$ Change in risk for increase of 10 years in the duration of HCV infection or age at HCV infection 
TABLE 3

Comparison of Ishak fibrosis scores in initial versus subsequent liver biopsy in Alaska Native and American Indian persons with chronic hepatitis $C$ infection $(n=52)$

\begin{tabular}{|c|c|c|c|c|c|c|c|c|}
\hline \multirow[b]{2}{*}{ Initial Ishak score } & \multicolumn{7}{|c|}{ Ishak score on repeat liver biopsy, n (\%) } & \multirow[b]{2}{*}{ Total, n (\%) } \\
\hline & 0 & 1 & 2 & 3 & 4 & 5 & 6 & \\
\hline 0 & $2(17)$ & $4(33)$ & $6(50)$ & 0 & 0 & 0 & 0 & $12(23)$ \\
\hline 1 & 0 & 0 & $9(75)$ & $1(8)$ & $2(17)$ & 0 & 0 & $12(23)$ \\
\hline 2 & 0 & $4(21)$ & $9(47)$ & $3(16)$ & $2(11)$ & $1(5)$ & 0 & $19(37)$ \\
\hline 3 & 0 & 0 & $5(63)$ & 0 & $1(12)$ & $1(12)$ & $1(12)$ & 8 (15) \\
\hline 4 & 0 & 0 & $1(100)$ & 0 & 0 & 0 & 0 & $1(2)$ \\
\hline Total & $2(4)$ & $8(15)$ & $30(58)$ & $4(8)$ & $5(10)$ & $2(4)$ & $1(2)$ & 52 \\
\hline
\end{tabular}

Fibrosis progression in persons with repeat biopsies

Individuals who had undergone multiple biopsies did not differ from persons with only one biopsy with respect to sex, initial Ishak score, ALT level at initial biopsy date, alcohol use, presence of steatosis on initial biopsy and genotype (data not shown). However, persons with multiple biopsies were older at the time of initial biopsy than those with only one biopsy (mean age 45 years versus 42 years $[\mathrm{P}=0.04])$. The mean time between biopsies for the 52 persons examined for fibrosis progression was 6.2 years (range 2.3 to 13.3 years). For the group, the mean Ishak fibrosis score on the first biopsy was 1.5 and increased to 2.3 on the most recent biopsy $(\mathrm{P}=0.002)$. Forty-six per cent (24 of 52) had little or no fibrosis (Ishak score of 0 to 1 ) on their first biopsy compared with 19\% (10 of 52) on the most recent biopsy (Table 3). Seventeen persons progressed one Ishak stage between biopsies and 14 progressed two stages or more. The mean liver fibrosis progression rate was 0.14 Ishak stages per year (range -0.33 to 0.87 ). Adjusted for initial Ishak fibrosis stage, progression was significantly associated with older age at initial biopsy $(\mathrm{P}=0.02)$ and HCV risk factors (blood transfusion/other versus intravenous drug use) $(\mathrm{P}=0.02)$ (Table 4).

Development of decompensated liver disease

The time from liver biopsy to progression to decompensated liver disease, hepatocellular carcinoma and liver-related death is presented in Table 5. Nine persons whose initial biopsy had an Ishak score of 4 or lower, and 15 persons with an initial Ishak score of 5 to 6 , developed decompensated liver disease during follow-up. One person with decompensated liver disease underwent a liver transplant. The overall incidence of decompensated liver disease after liver biopsy in persons with an Ishak score of 4 or lower was 1.04 cases/100 person years of follow-up compared with 14.8 cases/100 person years with an Ishak score of 5 to 6 . The relative incidence rate for persons with Ishak scores of 5 to 6 at biopsy compared with those who had Ishak scores of 4 or lower was $14.24 \%$ (95\% CI $6.24 \%$ to $34.02 \%$ ). A Kaplan-Meier survival curve (Figure 1) shows that the decompensated liver disease rate five years after liver biopsy was $5.0 \%$ for persons with an Ishak score of 4 or lower (95\% CI $0.6 \%$ to $9.4 \%$ ) versus $49.7 \%$ for persons with an Ishak score of 5 to $6(95 \%$ CI $27.8 \%$ to $71.6 \%)(\mathrm{P}<0.0001)$.

\section{DISCUSSION}

In the present cohort of Alaska Native and American Indian persons with chronic HCV infection, we examined predictors of advanced fibrosis on liver biopsy. We developed two models for multivariate analysis. In the first, which included surrogate markers of liver inflammation (ALT, AST/ALT ratio and AFP),
TABLE 4

Relationship between fibrosis progression and patient characteristics in $\mathbf{5 2}$ Alaska Native and American Indian persons with chronic hepatitis $\mathrm{C}$ virus infection who underwent multiple biopsies

\begin{tabular}{|c|c|c|c|c|}
\hline Characteristic/level & $\mathbf{n}$ & $\begin{array}{c}\text { Mean } \\
\text { fibrosis } \\
\text { progression* }\end{array}$ & $\mathbf{P}$ & $\begin{array}{c}P \text { (adjusted } \\
\text { for initial } \\
\text { Ishak fibrosis } \\
\text { stage) }\end{array}$ \\
\hline \multicolumn{3}{|l|}{ Sex } & 0.18 & 0.17 \\
\hline Female & 26 & 0.19 & & \\
\hline Male & 26 & 0.09 & & \\
\hline \multicolumn{3}{|c|}{ Age at initial liver biopsy, years } & 0.12 & 0.02 \\
\hline$<40$ & 23 & 0.09 & & \\
\hline $40-49$ & 19 & 0.13 & & \\
\hline$\geq 50$ & 10 & 0.26 & & \\
\hline \multicolumn{3}{|c|}{ Body mass index $\geq 30 \mathrm{~kg} / \mathrm{m}^{2}$} & 0.35 & 0.47 \\
\hline Yes & 22 & 0.18 & & \\
\hline No & 30 & 0.11 & & \\
\hline \multicolumn{3}{|c|}{ Knodell histological activity index } & 0.38 & 0.54 \\
\hline$\leq 7$ & 23 & 0.16 & & \\
\hline $8-9$ & 12 & 0.18 & & \\
\hline$\geq 10$ & 17 & 0.08 & & \\
\hline \multicolumn{3}{|c|}{ Hepatitis C virus genotype } & 0.37 & 0.40 \\
\hline 1 & 35 & 0.16 & & \\
\hline 2 & 12 & 0.05 & & \\
\hline 3 & 5 & 0.18 & & \\
\hline \multicolumn{3}{|c|}{ Hepatitis C virus infection duration, years } & 0.28 & 0.06 \\
\hline$<10$ & 19 & 0.11 & & \\
\hline 10 to $<20$ & 22 & 0.12 & & \\
\hline$\geq 20$ & 11 & 0.23 & & \\
\hline \multicolumn{3}{|l|}{ Risk factor } & $0.10^{\dagger}$ & $0.02^{\dagger}$ \\
\hline Intravenous drug use & 31 & 0.09 & & \\
\hline Blood transfusion & 8 & 0.25 & & \\
\hline Other & 13 & 0.18 & & \\
\hline \multicolumn{3}{|c|}{ Hepatitis C virus RNA level at first biopsy } & 0.66 & 0.84 \\
\hline$<500,000 \mathrm{IU} / \mathrm{mL}$ & 25 & 0.16 & & \\
\hline$\geq 500,000 \mathrm{IU} / \mathrm{mL}$ & 27 & 0.12 & & \\
\hline \multicolumn{3}{|c|}{$\begin{array}{l}\text { Alanine aminotransferase level at first biopsy }{ }^{\ddagger} \\
\quad(\text { normal }=40 \mathrm{U} / \mathrm{L} \text { ) }\end{array}$} & 0.31 & 0.37 \\
\hline$<2 \times U L N$ & 12 & 0.21 & & \\
\hline 2 to $<3 \times$ ULN & 20 & 0.13 & & \\
\hline$\geq 3 \times$ ULN & 18 & 0.11 & & \\
\hline
\end{tabular}

*Mean fibrosis progression = change in Ishak fibrosis score divided by number of years between biopsies; ${ }^{\dagger} P$ for blood transfusion/other combined versus intravenous drug use; ${ }^{\ddagger}$ Data not available for two patients at time of first biopsy. ULN Upper limit of normal 


\section{TABLE 5}

Mean time from liver biopsy stages to development of decompensated liver disease, hepatocellular carcinoma and liver-related death in Alaska Native and American Indian persons with chronic hepatitis C

\begin{tabular}{|c|c|c|c|c|}
\hline Liver biopsy fibrosis stage & Liver disease end point & $\mathbf{n}$ & Mean time, years (min, max) & Incidence rate per 100 persons/year \\
\hline \multirow[t]{3}{*}{ Ishak score $\leq 4$} & Decompensated liver disease & 9 & 5.1 (2 months, 8.0 years) & 1.04 \\
\hline & Hepatocellular carcinoma & 2 & 3.7 (1 month, 7.4 years) & * \\
\hline & Liver-related death & 3 & 6.7 (3.1 years, 9.4 years) & * \\
\hline \multirow[t]{3}{*}{ Ishak score 5-6 } & Decompensated liver disease & 15 & 4.4 (1 month, 11.0 years) & 14.8 \\
\hline & Hepatocellular carcinoma & 4 & 5.6 (3.8 years, 8.2 years) & * \\
\hline & Liver-related death & 6 & 5.7 (7 months, 9.8 years) & * \\
\hline
\end{tabular}

*Not calculated due to small sample sizes. Max Maximum; Min Minimum

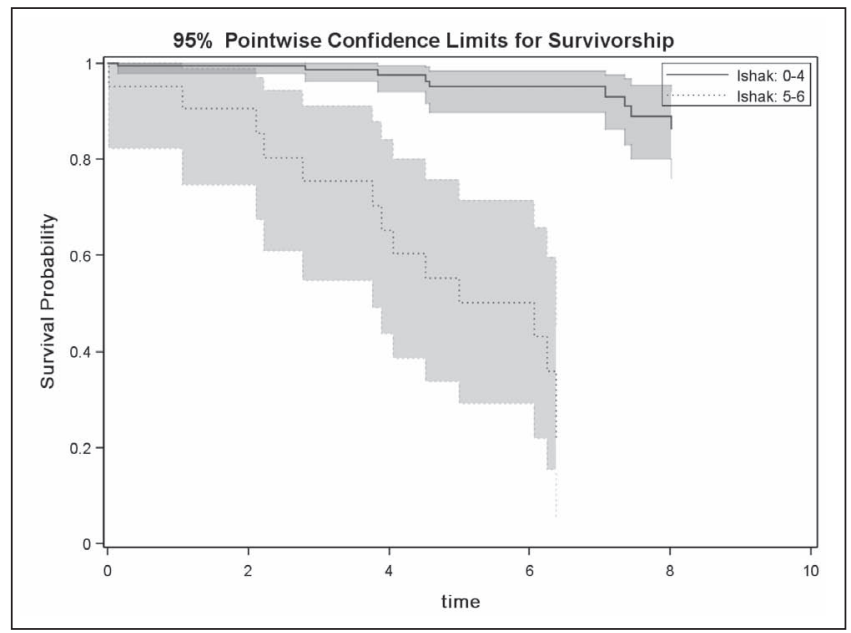

Figure 1) Survivorship curve for development of end-stage liver disease following liver biopsy in persons with chronic hepatitis $\mathrm{C}$ infection. The $y$-axis represents the probability that a person will remain free of end-stage liver disease following liver biopsy. The $x$-axis represents time in years since liver biopsy. The survivorship curve ends when sample sizes preclude the estimation of a confidence interval

Knodell HAI and AFP level of $8 \mathrm{ng} / \mathrm{mL}$ or higher were significantly associated with advanced fibrosis on biopsy (Ishak score of 3 to 6). When these markers were removed to distinguish factors that actually contribute to disease progression, the presence of steatosis on biopsy, type 2 diabetes mellitus and duration of HCV infection by 10-year intervals were independent predictors of severe disease.

We previously reported (15) an association of steatosis with fibrosis in this cohort, also finding that HCV genotype 3 was associated with the presence of moderate to severe steatosis. Many others (16-19) have noted the association of steatosis and HCV genotype 3, which has been attributed to viral factors, whereas steatosis in HCV genotype 1 infection has usually been attributed to metabolic factors. Although it has not been well studied and the mechanism is unclear, type 2 diabetes mellitus also has been shown to be a risk factor for the progression of liver fibrosis $(20,21)$. In one study (21), type 2 diabetes was independently associated with more severe fibrosis or the presence of cirrhosis in patients with chronic HCV. While other studies $(3,6)$ have reported HCV infection duration to be a risk factor for development of severe disease, its determination has been difficult and sometimes controversial. However, the Arctic Investigations Program of the Centers for Disease Control and
Prevention and the Alaska Native Tribal Health Consortium have maintained a serum bank for more than 30 years from previous research projects conducted in Alaska, thus, facilitating our ability to more accurately determine duration of infection than previous studies (14).

We found significant progression of fibrosis in the 52 persons in the present cohort who had undergone multiple biopsies, which were performed a mean of 6.2 years apart. This progression was associated with age at initial biopsy and risk factors (specifically, less progression with transmission by intravenous drug use). Independent association of age at time of biopsy with histological cirrhosis has been previously reported (5). Likewise, the association of advanced fibrosis on biopsy with transmission by blood transfusion has been reported (22). Our associations were only significant after adjustment for the initial Ishak score. These associations were not found in our overall biopsied cohort of 253 persons and, therefore, cannot be used to validate our findings in the present cohort. The small sample size of persons with repeat biopsies limited our power to establish risk factors for disease progression in a multivariate analysis.

We determined the incidence of developing decompensated liver disease according to baseline Ishak score in those with two or more liver biopsies. The incidence of progression to decompensated liver disease was 14 times higher in those with cirrhosis on initial liver biopsy (Ishak score of 5 to 6 ) than in those with an initial Ishak score of 4 or lower.

The current study had several limitations. Liver biopsies were performed in the present cohort for clinical reasons only, primarily as part of an evaluation for possible hepatitis $C$ treatment. Subsequent liver biopsies were also performed only for clinical reasons to determine whether disease progression occurred in persons not treated after a preceding biopsy, as suggested by clinical guidelines (10,23). Those biopsied had higher median ALT, AST and AFP levels, higher HCV RNA levels and were younger at age of consent than those not biopsied. This represents a selection bias and, therefore, limits our ability to generalize these findings to individuals who were not biopsied.

\section{CONCLUSION}

Our finding that steatosis, HCV infection duration and type 2 diabetes mellitus in an indigenous population were independent predictors of advanced fibrosis on liver biopsy confirmed those of other investigators. In addition, we also found evidence of fibrosis progression in participants who underwent repeat biopsies. Importantly, we demonstrated that the incidence of developing decompensated liver disease was dramatically higher in those who had cirrhosis present on initial biopsy. 
FUNDING: This study was supported by University of Washington (Washington, USA) National Institutes of Health grants A48214 and A1066209, the Liver Disease and Hepatitis Program of the Alaska Native Tribal Health Consortium, Anchorage (Alaska, USA), and the Arctic Investigations Program of the National Center for Infectious Disease, Centers for Disease Control and Prevention, Anchorage, Alaska, USA).

\section{REFERENCES}

1. Wright M, Goldin R, Fabre A, et al. Measurement and determinants of the natural history of liver fibrosis in hepatitis $\mathrm{C}$ virus infection: A cross-sectional and longitudinal study. Gut 2003;52:574-9.

2. Poynard T, Ratziu V, Charlotte F, Goodman Z, McHutchison J, Albrecht J. Rates and risk factors of liver fibrosis progression in patients with chronic hepatitis C. J Hepatol 2001;34:730-9.

3. Danta M, Dore GJ, Hennessy L, et al. Factors associated with severity of hepatic fibrosis in people with chronic hepatitis C infection. Med J Aust 2002;177:240-5.

4. Bruce MG, Bruden D, McMahon BJ, et al. Clinical significance of elevated alpha-fetoprotein in Alaska Native patients with chronic hepatitis C. J Viral Hepatol 2008;15:179-87.

5. Minola E, Prati D, Suter F, et al. Age at infection affects the long-term outcome of transfusion-associated chronic hepatitis C. Blood 2002:99:4588-91.

6. Monto A, Patel K, Bostrom A, et al. Risks of a range of alcohol intake on hepatitis C-related fibrosis. Hepatology 2004;39:826-34.

7. McCormick SE, Goodman ZD, Maydonovitch CL, Sjogren MH. Evaluation of liver histology, ALT elevation, and HCV RNA titer in patients with chronic hepatitis C. Am J Gastroenterol 1996;91:1516-22.

8. Poynard T, Bedossa P, Opolon P. Natural history of liver fibrosis progression in patients with chronic hepatitis $\mathrm{C}$. Lancet 1997;349:825-30.

9. McMahon BJ, Hennessy T, Christensen C, et al. Epidemiology and risk factors for hepatitis $\mathrm{C}$ in Alaska Natives. Hepatology 2004:39:324-32.

10. Strader DB, Wright T, Thomas DL, Seeff L. Diagnosis, management and treatment of hepatitis C. Hepatology 2004;39:1147-71.

11. Davidson F, Simmonds P, Ferguson JC, et al. Survey of major genotypes and subtypes of hepatitis $\mathrm{C}$ virus using RFLP of sequences amplified from the 5' non-coding region. J Gen Virol 1995; 76:1197-204.

12. Knodell RG, Ishak KG, Black WC, et al. Formulation and application of a numerical scoring system for assessing histological activity in asymptomatic chronic active hepatitis. Hepatology 1981;1:431-5.

13. Ishak K, Baptista A, Bianchi L, et al. Histological grading and staging of chronic hepatitis. J Hepatol 1995;22:696-9.

14. Bruden D, McMahon BJ, Hennessy TW, et al. Estimating the date of hepatitis $\mathrm{C}$ virus infection from patient interviews and antibody tests on stored sera. Am J Gastroenterol 2004;99:1518-22.

15. Livingston SE, Deubner H, McMahon BJ, et al. Steatosis and hepatitis $\mathrm{C}$ in an Alaska Native/American Indian population. Int J Circumpolar Health 2006;6:253-60.

16. Cholet F, Nousbaum JB, Richecoeur M, et al. Factors associated with liver steatosis and fibrosis in chronic hepatitis $C$ patients. Gastroenterol Clin Biol 2004;28:272-8.

17. Westin J, Nordlinder H, Lagging M, Norkrans G, Wejstal R. Steatosis accelerates fibrosis development over time in hepatitis C virus genotype 3 infected patients. J Hepatol 2002;37:837-42.

18. Adinolfi L, Gambardella M, Andreana A, Tripodi MF, Utili R, Ruggiero G. Steatosis accelerates the progression of liver damage of chronic hepatitis $\mathrm{C}$ patients and correlates with specific HCV genotype and visceral obesity. Hepatology 2001;33:1358-63.

19. Hu K-Q, Hyulo N, Esrailian E, et al. Overweight and obesity, hepatic steatosis, and progression of chronic hepatitis $\mathrm{C}$ : A retrospective study on a large cohort of patients in the United States. J Hepatol 2004;40:147-54.

20. Kita Y, Mizukoshi E, Takamura T, et al. Impact of diabetes mellitus on prognosis of patients infected with hepatitis $\mathrm{C}$ virus. Metabolism 2007;56:1682-8.

21. Papatheodoridis GV, Chrysanthos N, Savvas S, et al. Diabetes mellitus in chronic hepatitis B and C: Prevalence and potential association with the extent of liver fibrosis. J Viral Hepatol 2006;13:303-10.

22. Gordon SC, Elloway RS, Long JC, Dmuchowski CF. The pathology of hepatitis $\mathrm{C}$ as a function of mode of transmission: Blood transfusion vs. intravenous drug use. Hepatology 1993;18:1338-43.

23. Wong JB, Koff RS. Watchful waiting with periodic liver biopsy versus immediate empirical therapy for histologically mild chronic hepatitis C. A cost-effectiveness analysis. Ann Intern Med 2000;133:665-75. 


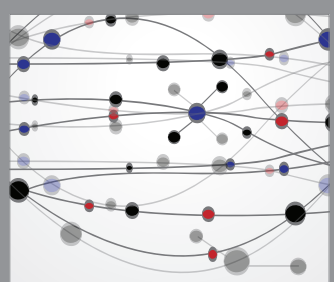

The Scientific World Journal
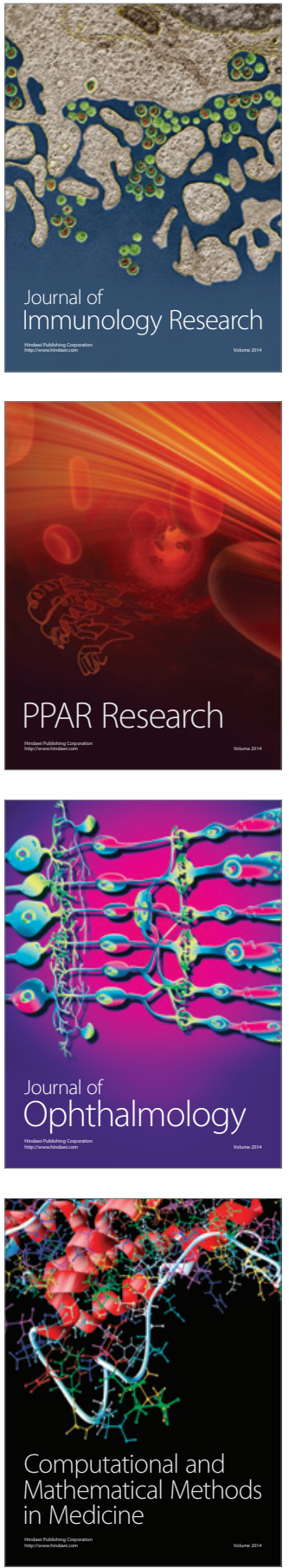

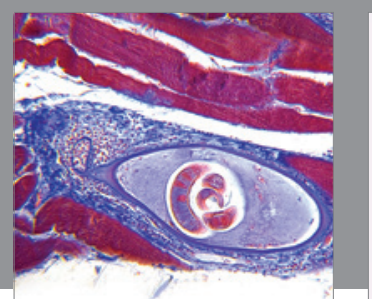

Gastroenterology Research and Practice

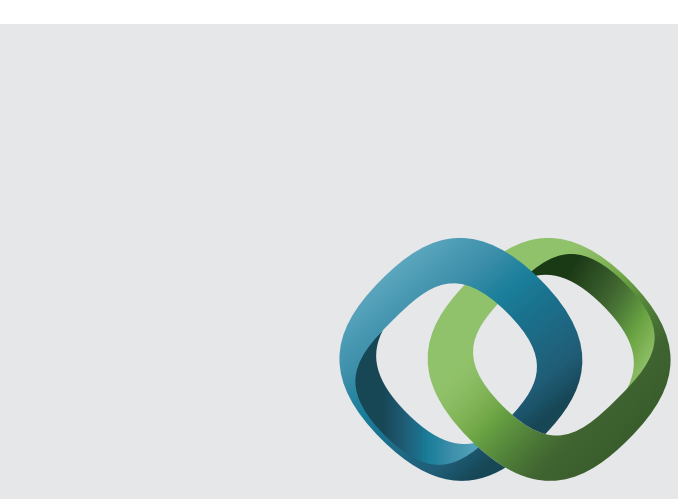

\section{Hindawi}

Submit your manuscripts at

http://www.hindawi.com
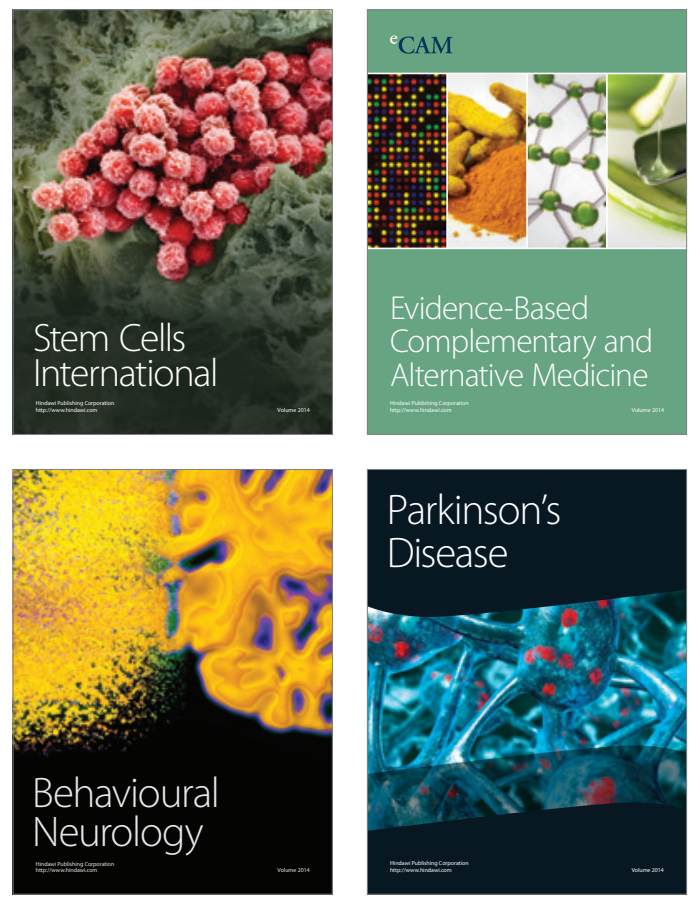
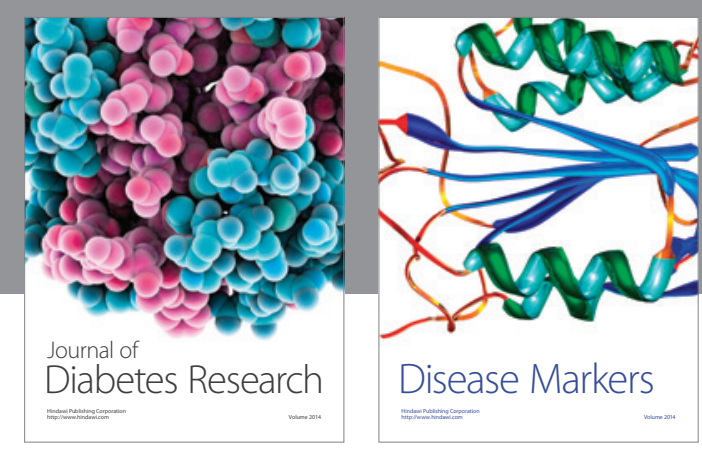

Disease Markers
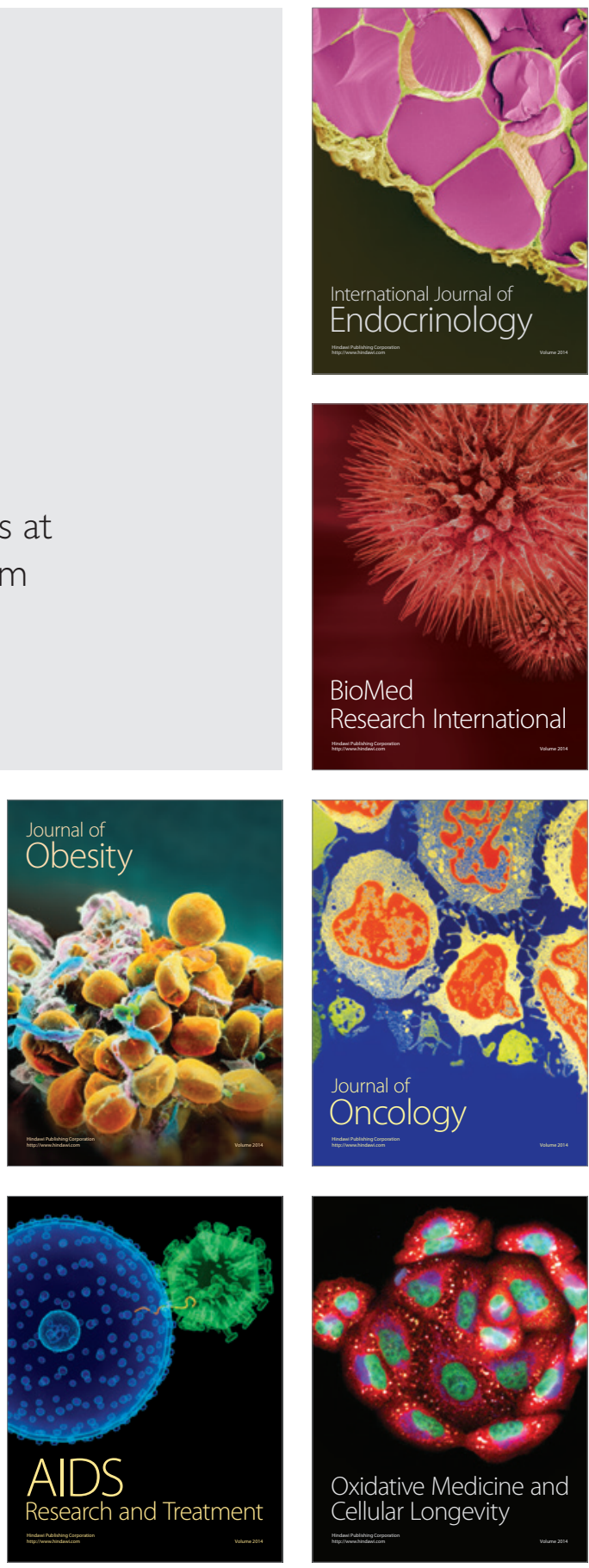